Tol, J., Swinkels, I.C.S., Veenhof, C. Welke cliënten hebben volgens de diëtist voldoende aan vier uur diëtetiek per kalenderjaar? TSG: Tijdschrift voor Gezondheidswetenschappen: 2012, 90(3), 176-183

\begin{tabular}{|l|l|}
\hline Postprint Version & 1.0 \\
\hline Journal website & http://vb23.bsl.nl/frontend/index.asp?custom_product_id=1388- \\
& 7491\&product_id=\{68B1EBF1-7393-458F-BF75-BDB5E9A3DAE9\} \\
\hline Pubmed link & \\
\hline DOI & \\
\hline
\end{tabular}

This is a NIVEL certified Post Print, more info at http://www.nivel.eu

\title{
Welke cliënten hebben volgens de diëtist voldoende aan vier uur diëtetiek per kalenderjaar?
}

\author{
J. TOL* ,I.C.S. SWINKELS**,C. VEENHOF*** \\ * NIVEL, Utrecht \\ ** projectleider Landelijke informatievoorziening paramedische zorg, NIVEL, Utrecht \\ *** programmaleider paramedische zorg, NIVEL, Utrecht
}

Doel: Sinds 2005 wordt vanuit de basisverzekering vier uur diëtetiek per kalenderjaar vergoed. Het doel van dit onderzoek is inzicht te geven in factoren die volgens diëtisten geassocieerd zijn met het wel of niet voldoende hebben aan vier behandeluren. Methoden: In een onderzoek (LiPZ) registreerden 25 vrijgevestigde diëtisten in de praktijksoftware (Evry) zorggerelateerde gegevens van cliënten die zij behandelden. Aan het einde van de kalenderjaren 2006 t/m 2009 beoordeelden diëtisten in totaal 5612 maal of vier behandeluren voor de betreffende cliënt voldoende was. De gegevens werden geanalyseerd door middel van logistische multilevel analyse. Resultaten: Gemiddeld had naar het oordeel van diëtisten $21 \%$ onvoldoende aan vier behandeluren (range 1-89\%). Een tekort aan vier behandeluren kwam voornamelijk voor bij vrouwen, cliënten met psychische of verstandelijke problemen, een te hoog lichaamsgewicht, binge-eating disorder, meervoudige diagnosen, of de combinatie van een te hoog lichaamsgewicht en binge-eating disorder of hypertensie. Daarentegen hadden ouderen, cliënten met het eerste consult tussen juli en december en cliënten met een follow-up behandeling vaker voldoende aan vier behandeluren. Conclusie en discussie: Een grote groep cliënten heeft volgens diëtisten onvoldoende aan vier behandeluren. Echter, tussen diëtisten zijn grote verschillen ten aanzien van het beoordelen of vier behandeluren voldoende zijn. Meer onderzoek is nodig om te achterhalen waar deze verschillen door komen. Ook is bij cliënten met een tekort aan vier behandeluren onderzoek nodig naar het resultaat van de behandeling en de benodigde extra behandeltijd.

Aim: Since 2005, dietetic treatment is reimbursed by the standardized primary health insurance coverage for up to a maximum of four hours per calendar year. The purpose of this study is to give insight on the dietitian's perception of the factors that are associated with the sufficiency of four hours of dietetics. Methods: In this observational study, 25 Dutch dietitians working in private practices registered patients healthcare-related information in a specific software program. At the end of the years 2006 until 2009 dietitians filled-out in 5612 cases whether four hours of dietetics were sufficient. Data were analyzed using logistic multi-level analysis. Results: According to the dietitian, four hours were insufficient in $21 \%$ of the patients (range 1-89\%). Four hours were mainly insufficient in females, patients with psychological or intellectual disability, overweight, binge-eating disorder, multiple diagnoses, or overweight with binge-eating disorder or hypertension. On the other hand, four hours of reimbursement a year was often sufficient in elderly patients, patients with the first consultation between July or 
December, or with a follow-up. Conclusion and discussion: Four hours of dietetics per year are insufficient in a large number of patients. Yet dietitians' decision making process varied widely regarding the patient's sufficiency of four hours per year. More research is necessary to outline the causes of these differences. In addition, research is needed in patients with insufficient dietetic reimbursement to examine the results of the treatment and the necessary extra treatment time.

\section{INLEIDING}

Sinds 1 januari 2005 krijgen cliënten die met een medische indicatie door een arts zijn verwezen naar de extramuraal werkende diëtist vanuit de basisverzekering vier uur diëtetiek per kalenderjaar vergoed. 1 Uit jaarcijfers van de Landelijke Informatievoorziening Paramedische Zorg (LiPZ) blijkt dat vier uur diëtetiek volgens de diëtist bij gemiddeld één op de vier cliënten onvoldoende is. 2 Eerder onderzoek laat zien dat bepaalde cliëntgroepen vaker onvoldoende hebben aan vier uur diëtetiek per kalenderjaar dan andere groepen. Voorbeelden hiervan zijn vrouwen, en cliënten met een te hoog lichaamsgewicht, binge eating disorder of psychiatrische problemen. 3 Echter, de resultaten uit dat onderzoek zijn gebaseerd op gegevens met betrekking tot een korte tijdsperiode en een kleine steekproef. Hierdoor zijn bepaalde behandelingsgerelateerde effecten niet onderzocht.

Meer inzicht in de verschillende factoren die bepalen of vier uur diëtetiek per kalenderjaar toereikend is, geeft aanknopingspunten voor bijstelling van het vergoedingsbeleid omtrent de diëtetiek. Behalve vanuit beleidsmatig oogpunt is dit inzicht ook van belang voor de diëtist, de verwijzend arts en de cliënt. Diëtisten kunnen bijvoorbeeld eventuele extra kosten voor de cliënt beter inschatten en zo nodig de behandeling aanpassen.

De verschillende factoren die bepalen of cliënten voldoende hebben aan vier uur diëtetiek per kalenderjaar kunnen worden onderverdeeld in vier groepen. De eerste groep factoren bestaat uit de demografische kenmerken van de cliënt. 4 De tweede groep factoren bestaat uit gezondheidsgerelateerde kenmerken van de cliënt, zoals de diagnose. Mogelijk hebben cliënten met een bepaalde diagnose bijvoorbeeld vaker tekort aan vier behandeluren per kalenderjaar. Er wordt in de artsenwijzer diëtetiek namelijk per diagnose een indicatie voor de benodigde behandeltijd beschreven. Hierin staat bijvoorbeeld beschreven dat het zorggebruik bij cliënten met meervoudige diagnosen of een communicatiebeperking met 10 kwartier per behandeling kan toenemen. 5 Deze indicaties zijn echter gebaseerd op ervaringen van diëtisten. De derde groep factoren die een rol spelen zijn de behandelingsgerelateerde kenmerken. Zo kan het initiatief van een cliënt om de behandeling te starten van invloed zijn op het wel of niet voldoende hebben aan vier behandeluren. Een cliënt die op eigen initiatief een verwijsbriefje bij de huisarts heeft gehaald om een dieetbehandeling te starten, kan bijvoorbeeld gemotiveerder zijn dan een cliënt die op initiatief van de huisarts een dieetbehandeling start. Ook kan het kwartaal waarin het eerste consult in een bepaald jaar plaatsvindt bepalend zijn doordat het vergoedingsbeleid per kalenderjaar geregeld is. Verder kan het dieetverleden van de cliënt ook van invloed zijn op de mate waarin vier uur toereikend is. De vierde groep factoren bestaat uit therapeut gerelateerde kenmerken, 6 zoals de demografische kenmerken van de diëtist. Mogelijk bestaan er tussen diëtisten verschillen in de manier waarop zij de zorgbehoefte van cliënten schatten.

Inmiddels zijn gegevens beschikbaar over een groter aantal cliënten en een langere tijdsperiode. Hierdoor kunnen verdergaande analyses worden uitgevoerd naar de mate waarin cliënten volgens de diëtist voldoende hebben aan vier behandeluren per kalenderjaar. Het doel van het huidige onderzoek is meer inzicht te krijgen in de verschillende factoren die van invloed zijn op het volgens de diëtist onvoldoende hebben aan vier uur diëtetiek per kalenderjaar. Het tweede doel is te onderzoeken of er tussen diëtisten onderling verschil bestaat in beoordelingswijze ten aanzien van de vraag of vier uur diëtetiek per kalenderjaar voor een cliënt toereikend is.

\section{METHODE}

\section{Onderzoeksopzet}

Dit onderzoek is uitgevoerd op basis van gegevens van de Landelijke Informatievoorziening Paramedische Zorg (LiPZ). LiPZ is een landelijk geautomatiseerd registratienetwerk van extramuraal werkende diëtisten, 
fysiotherapeuten en oefentherapeuten Cesar en Mensendieck waarin continu zorggerelateerde gegevens worden verzameld. In 2006 is LiPZ gestart met het monitoren van de zorg aan cliënten die bij de vrijgevestigde diëtist in behandeling zijn.

\section{Deelnemers}

In dit onderzoek zijn 25 vrijgevestigde diëtisten geïncludeerd, die tussen 2006 en 2010 in LiPZ participeerden. Zij waren allen werkzaam in solopraktijken. De demografische kenmerken van de diëtisten zijn vergeleken met de demografische kenmerken van vrijgevestigde diëtisten die lid waren van de Nederlandse Vereniging van Diëtisten (NVD) of van de Diëtisten Coöperatie Nederland (DCN). 2,3 Hierbij werden geen significante verschillen gevonden wat betreft de regio en de mate van verstedelijking in het gebied waar de diëtisten gevestigd waren. De LiPZ diëtisten waren in 2008 en 2009 gemiddeld ouder en langer afgestudeerd $(p<0.05)$ dan de vrijgevestigde diëtisten die lid waren van de NVD of van de DCN. Over de jaren 2006 en 2007 werden er op deze punten geen significante verschillen gevonden.

\section{Gegevensverzameling}

De verzamelde gegevens werden door diëtisten geregistreerd in de praktijksoftware (Evry). Hierbij ging het naast declaratiegegevens om een aantal extra gegevens ten behoeve van het LiPZ-onderzoek. De gegevens hadden betrekking op de cliënt, de verwijzing, het gezondheidsprobleem, de behandeling en de evaluatie van de behandeling. Om het invullen van deze aanvullende gegevens mogelijk te maken werd een aparte LiPZ-module in de praktijksoftware ingebouwd. Maandelijks werden declaratiegegevens en LiPZgegevens, zonder privacygevoelige informatie, uitgespoeld uit de praktijksoftware en via een beveiligde website naar het NIVEL verzonden. De gegevens die voor het huidige onderzoek zijn gebruikt, werden gecodeerd aangeleverd en gecontroleerd op kwaliteit en volledigheid.

\section{De uitkomstvariabele}

De diëtisten beoordeelden aan het einde van ieder kalenderjaar of vier uur diëtetiek voor de betreffende cliënt voldoende of onvoldoende was geweest. De uitkomstvariabele werd soms meerdere keren per cliënt ingevuld, aangezien een behandeling meerdere jaren kon duren. Over een periode van vier jaar tijd werd er door 25 diëtisten bij 4942 cliënten in totaal 5612 maal beoordeeld of vier uur diëtetiek voor de betreffende cliënt voldoende was geweest, of dat het voor de behandeling van de cliënt beter was geweest als hij meer dan vier uur diëtetiek te besteden had gehad.

\section{De onafhankelijke variabelen}

In deze studie werden verschillende onafhankelijke variabelen gebruikt die betrekking hadden op de demografische kenmerken, de gezondheidsgerelateerde kenmerken en de behandeling gerelateerde kenmerken.

\section{Demografische kenmerken van de cliënt}

De gebruikte demografische kenmerken van de cliënt zijn geslacht, leeftijd, opleidingsniveau en etnische afkomst. Ook is de stedelijkheidsgraad van de woonplaats van de cliënt onderzocht. De etnische afkomst werd door diëtisten geregistreerd volgens de definitie van het Centraal Bureau voor de Statistiek. In de huidige studie zijn westerse allochtonen binnen de categorie autochtonen ingedeeld. Het hoogst behaalde opleidingsniveau van de cliënt werd door de diëtisten in vier categorieën geregistreerd: laag (speciaal onderwijs, basisonderwijs, VMBO-praktijk), middelbaar (MULO, MMS, MAVO, VMBO-theoretisch, HAVO, MBO), hoger (HBS, VWO, HBO, WO) en anders (zoals cliënten die nog in opleiding waren). De stedelijkheidsgraad van de woonplaats van de cliënt werd bepaald aan de hand van de vier cijfers van zijn postcode en kon worden ingedeeld in drie categorieën: laag ( $<1000$ adressen per km2), middel (1000-1500 adressen per km2) en hoog (>1500 adressen per km2).

\section{Gezondheidsgerelateerde kenmerken}

De gebruikte gezondheidsgerelateerde kenmerken van de cliënt zijn het hebben van psychische-, verstandelijke- of communicatieproblemen. Daarnaast werd de medische informatie uit de diëtistische diagnose gebruikt om het gezondheidsprobleem van de cliënt verder te specificeren. Per cliënt werden maximaal vier diagnoses geregistreerd die voorkwamen in de artsenwijzer diëtetiek. In deze studie zijn zowel de meest voorkomende enkelvoudige als meest voorkomende combinaties van diagnoses onderzocht. Al de gebruikte gezondheidsgerelateerde kenmerken zijn geregistreerd volgens het oordeel van de diëtist. 


\section{Behandelingsgerelateerde kenmerken}

In deze studie werden verschillende behandelingsgerelateerde kenmerken onderzocht, zoals de jaarlijkse bepaling van het dieetverleden van de cliënt. Hierbij werd ieder kalenderjaar onderscheid gemaakt tussen cliënten die in de afgelopen vijf jaar geen eerdere diëtetiek hadden ontvangen, of wel eerdere diëtetiek hadden ontvangen maar waarbij de behandeling was afgesloten, of een follow-up behandeling hadden ontvangen. Daarnaast werd ieder kalenderjaar het kwartaal vastgesteld waarin het eerste consult had plaatsgevonden. Verder werd bij aanvang van de behandeling geregistreerd of het initiatief om de behandeling te starten bij de cliënt lag of bij de verwijzer.

\section{Demografische kenmerken van de diëtist}

De gebruikte demografische kenmerken van de diëtist waren leeftijd en geslacht. De leeftijd van de diëtist werd ieder kalenderjaar bepaald op datum van het eerste consult van de betreffende cliënt.

\section{Statistische analyse}

De algemene karakteristieken van de steekproef werden geanalyseerd met beschrijvende statistieken in het softwareprogramma Stata versie 11.0. Om antwoord te geven op de hoofdvragen en om te corrigeren tussen de afhankelijkheid van gegevens, werd logistische multilevel analyse toegepast (in het softwareprogramma MLWin versie 2.15). De geclusterde gegevens uit deze studie konden in drie niveaus worden ingedeeld: niveau 1) de diëtisten; niveau 2) de cliënten; niveau 3) het aantal kalenderjaren waarin per cliënt gemeten was of vier behandeluren voldoende waren.

Het statistisch model bevatte de demografische kenmerken van de cliënt, de gezondheidsgerelateerde kenmerken, de behandelingsgerelateerde kenmerken en de demografische kenmerken van de diëtist. Hierdoor werd het onderzochte verband tussen een bepaald kenmerk en de uitkomstvariabele gecorrigeerd voor een mogelijke invloed van de andere factoren in het model. Voor onafhankelijke variabelen waarvan waardes niet bekend waren werd een extra categorie 'onbekend' toegevoegd. Om te controleren of deze methode invloed had op de resultaten van deze studie zijn sensitiviteitsanalyses uitgevoerd (zie box 1).

\section{[BOX 1]}

Per onafhankelijke variabele werd de odds ratio (OR) berekend. Deze maat geeft de verhouding weer van de kans op het onvoldoende hebben aan vier uur diëtetiek per kalenderjaar ten opzichte van de kans om voldoende te hebben. Om de leesbaarheid van de resultaten in dit artikel te vergroten is er gekozen om de interpretatie van de OR eenvoudiger te omschrijven. Wanneer de OR bijvoorbeeld voor geslacht groter is dan 1 betekend dit dat vrouwen vaker onvoldoende hebben aan vier behandeluren dan mannen (waarbij mannen de zogeheten referentie categorie zijn). Is de OR kleiner dan 1, dan hebben vrouwen minder vaak onvoldoende aan vier behandeluren ten opzichte van mannen. Een variabele is significant geassocieerd met de uitkomstvariabele bij een $p$-waarde kleiner dan 0,01.

\section{RESULTATEN}

\section{Algemene karakteristieken}

De cliënten in deze studie hadden een gemiddelde leeftijd van 47,8 jaar (standaarddeviatie 19,4). Ongeveer tweederde was vrouw en zes procent had een niet-westerse allochtone afkomst. De meest voorkomende enkelvoudige diagnose was een te hoog lichaamsgewicht bij volwassenen (25\%). De meerderheid van de cliënten had meervoudige diagnosen (52\%). De meest voorkomende combinatie was een te hoog lichaamsgewicht en diabetes (9\%) (zie tabel 1).

\section{[TABEL 1.]}

\section{Factoren die bepalen of vier uur diëtetiek per kalenderjaar voldoende is}

Diëtisten hadden de toereikendheid van vier uur diëtetiek per kalenderjaar vaker als onvoldoende beoordeeld bij vrouwen, mensen met psychologische problemen, verstandelijke problemen, een te hoog lichaamsgewicht bij volwassenen, binge-eating disorder, of meervoudige diagnosen (zie tabel 1). Twee specifieke voorbeelden van meervoudige diagnosen met een hogere kans om onvoldoende te hebben waren een combinatie van een te hoog lichaamsgewicht en binge-eating disorder of hypertensie. Cliënten hadden daarnaast vaker onvoldoende aan vier behandeluren als ze bij aanvang van de behandeling eerdere diëtistische zorg hadden gehad vergeleken met cliënten die geen eerdere diëtetiek hadden gehad. 
Daarentegen hadden diëtisten de toereikendheid van vier uur diëtetiek per kalenderjaar vaker als voldoende beoordeeld bij cliënten met een follow-up behandeling dan cliënten die nog geen eerdere diëtetiek gehad hadden. Verder hadden cliënten met een eerste consult in het derde of vierde kwartaal van het jaar vaker voldoende aan vier behandeluren dan cliënten met een consult in het eerste kwartaal. Ook hadden cliënten vaker voldoende aan vier behandeluren wanneer zij ouder waren dan 60 jaar, vergeleken met 40 tot 60 jarigen (de meest voorkomende leeftijdsgroep), of wanneer zij in behandeling waren bij een diëtist ouder dan 48 jaar in plaats van bij een diëtist jonger dan 48 jaar.

\section{Verschillen in de beoordeling van de noodzakelijke behandelduur}

Na correctie van de demografische kenmerken, de gezondheidsgerelateerde kenmerken en de behandelingsgerelateerde kenmerken uit deze studie had gemiddeld $21,0 \%$ van de cliënten volgens de diëtist onvoldoende aan vier behandeluren per kalenderjaar. Het gemiddelde varieerde tussen diëtisten onderling van 1,2\% tot 89,4\% (zie figuur 1). Dit geeft aan dat er tussen diëtisten grote verschillen bestaan ten aanzien van het beoordelen of vier uur diëtetiek per kalenderjaar voor een cliënt toereikend is.

\section{[FIGUUR 1.]}

\section{DISCUSSIE}

Voorafgaand aan de invoering van de vergoeding van vier uur diëtetiek per kalenderjaar vanuit de basisverzekering heeft het Ministerie van Volksgezondheid, Welzijn en Sport (VWS) koepels van diëtisten en thuiszorginstellingen geraadpleegd om te achterhalen hoeveel uur dieetzorg een cliënt gemiddeld per jaar gebruikt. Zij verwachtten dat $90 \%$ van de cliënten voldoende zou hebben aan vier behandeluren dieetadvisering per kalenderjaar. 1 Destijds is er tevens een landelijke enquête onder extramuraal werkende diëtisten uitgezet. Daaruit bleek dat het merendeel van de vrijgevestigde diëtisten verwachtte dat vier uur diëtetiek per kalenderjaar voor minder dan $60 \%$ van hun cliënten genoeg zou zijn. 7 Uit de huidige studie blijkt echter dat de vergoeding volgens de diëtist voor $80 \%$ van de cliënten toereikend is. Dit percentage ligt ongeveer vijf procent hoger dan eerder verschenen LiPZ jaarcijfers. 2,3 De resultaten van het huidige onderzoek geven een betrouwbaarder beeld omdat de berekeningen gebaseerd zijn op vier kalenderjaren in plaats van één kalenderjaar. Daarbij is er in dit onderzoek rekening gehouden met verschillende kenmerken van de cliënt, de behandeling en de diëtist. Onlangs heeft het Ministerie van VWS besloten om de vergoeding van dieetadvisering per 1 januari 2012 uit de basisverzekering te halen, met uitzondering van dieetadvisering die wordt gegeven als onderdeel van gecoördineerde multidisciplinaire zorg voor patiënten met diabetes mellitus, chronische obstructieve longziekten of met een cardiovasculair risico. 8 Momenteel (oktober 2011) is het nog niet duidelijk hoe de vergoeding geregeld wordt voor mensen die naast één van deze aandoeningen ook andere gezondheidsproblemen hebben zoals diabetes en een te hoog lichaamsgewicht. Daarnaast is het nog niet duidelijk in hoeverre de vergoeding van dieetadvisering in de aanvullende verzekeringen wordt opgenomen. De resultaten uit dit onderzoek kunnen aanknopingspunten bieden voor de onderhandelingen tussen diëtisten en zorggroepen of zorgverzekeraars over de vergoeding van dieetzorg.

Deze studie toont aan dat naar het oordeel van diëtisten vrouwen meer zorg nodig hebben dan mannen. Dit resultaat komt overeen met het resultaat van studies binnen andere beroepsgroepen. 9,10 Daarentegen hebben oudere cliënten volgens de diëtist minder zorg nodig dan jongeren. Studies binnen andere beroepsgroepen tonen aan dat ouderen over het algemeen juist meer zorg gebruiken. 11 Mogelijk hebben ouderen lagere verwachtingen van de diëtistische behandeling en hebben zij daardoor aan minder behandeluren voldoende. Meer onderzoek is nodig om deze verklaring te bevestigen. Verder was de kans om volgens de diëtist niet voldoende te hebben aan vier behandeluren voor autochtone cliënten iets groter dan voor allochtone cliënten. Er kan gediscussieerd worden over de betrouwbaarheid van dit resultaat. Slechts 6\% van de cliënten in deze studie had namelijk een niet-westerse allochtone afkomst. Dit percentage is vrij laag vergeleken met het percentage niet-westerse allochtonen in de Nederlandse bevolking (11\%). 12

Diëtisten beoordeelden de toereikendheid van vier uur diëtetiek per kalenderjaar vaker als onvoldoende bij cliënten met psychische problemen, verstandelijke problemen, een te hoog lichaamsgewicht, binge-eating disorder of meervoudige diagnosen dan cliënten zonder deze gezondheidsproblemen. Deze resultaten komen overeen met die uit eerder verschenen onderzoek. 3,6 Het verwachtte effect voor mensen met een communicatiebeperking werd niet gevonden. Het lijkt er dus op dat cliënten met een 
communicatiebeperking niet meer zorg behoeven dan cliënten zonder een deze beperking. Nieuwe resultaten uit deze studie tonen aan dat cliënten met een combinatie van een te hoog lichaamsgewicht en binge-eating disorder of hypertensie vaker onvoldoende hebben aan vier behandeluren dan cliënten met een ander gezondheidsprobleem. Verder blijkt uit deze studie dat geen van de onderzochte

gezondheidsproblemen $(p<0,01)$ geassocieerd is met het volgens de diëtist voldoende hebben aan vier uur per kalenderjaar. Wel zijn er bepaalde behandelingsgerelateerde kenmerken die bepalen of cliënten volgens de diëtist vaker voldoende hebben aan vier uur diëtetiek. Zo hebben cliënten met een follow-up behandeling vaker voldoende aan vier behandeluren dan cliënten zonder een eerdere diëtistische behandeling. Cliënten met een follow-up behandeling zijn waarschijnlijk al verder in het behalen van de behandeldoelen of in behandeling voor terugvalpreventie of een jaarlijkse controle. Daarentegen hebben cliënten met eerdere diëtistische zorg bij aanvang van de behandeling vaker onvoldoende aan vier behandeluren dan cliënten zonder een eerdere diëtistische behandeling. Dit resultaat komt overeen met eerder onderzoek. 3 De achterliggende hypothese hierbij is dat cliënten met een dieetverleden vaak langdurig dezelfde voedingsgerelateerde problemen hebben, die samenhangen met andere gecompliceerde factoren die het probleem in stand houden.

Een belangrijk resultaat is dat het huidige vergoedingsbeleid een nadelige kant heeft voor cliënten die in de eerste helft van het kalenderjaar de behandeling starten. Zij hebben immers volgens de diëtist vaker onvoldoende aan vier behandeluren. Dit is oneerlijk te noemen aangezien het huidige vergoedingsbeleid juist een voordelige kant heeft voor cliënten met een eerste consult in het derde of vierde kwartaal. Zij hebben juist vaker voldoende aan vier behandeluren. Wanneer het huidige vergoedingsbeleid aangepast zou worden in vergoeding van vier behandeluren per jaar, in plaats van per kalenderjaar, dan zou een grotere groep cliënten dan nu het geval is niet voldoende hebben aan vier uur diëtetiek.

Uit deze studie blijkt dat er tussen diëtisten grote verschillen bestaan ten aanzien van het beoordelen of vier uur diëtetiek per kalenderjaar voor een cliënt voldoende is. Het is niet bekend welke overwegingen diëtisten hebben genomen bij het maken van hun oordeel over de toereikendheid. De verschillen tussen diëtisten konden niet verklaard worden door de demografische kenmerken van de cliënt of de diëtist, de meest voorkomende gezondheidsproblemen of de behandelingsgerelateerde kenmerken. Wellicht wordt dit verschil veroorzaakt door factoren als verschil in kennis, werkervaring, 12 de manier van behandelen, 13,14 of werkdruk. 15 Een groot verschil in werkwijze tussen diëtisten kan duiden op een verschil in kwaliteit van de diëtistische zorg. Over het algemeen kan variatie tussen vrijgevestigde zorgverleners verminderd worden door meer te werken volgens richtlijnen. 16 Een aandachtspunt hierbij is de beschikbare kennis waarop de huidige dieetbehandelingsrichtlijnen zijn gebaseerd. De huidige beschikbare wetenschappelijke kennis met betrekking tot de effectiviteit van behandelmethoden bij specifieke aandoeningen, comorbiditeit en de behandeltijd die hiervoor nodig is, is niet volledig. Hierdoor is er veel ruimte voor de diëtist om de behandeling en behandeltijd naar eigen inbreng in te delen. Voor het vergroten van de transparantie binnen de diëtetiek is het van belang meer inzicht in verschillen tussen diëtisten en het effect daarvan op de werkwijze van diëtisten te onderzoeken.

Een beperking van het onderzoek is het relatief lage aantal deelnemende diëtisten. De oorzaak van verschillen tussen diëtisten zal nader onderzocht moeten worden onder een grotere steekproef van diëtisten. Echter de huidige steekproef is representatief qua regio en de mate van verstedelijking van het gebied waarin de praktijk gevestigd is, vergeleken met de vrijgevestigde diëtisten die lid zijn van de NVD en van de DCN. Een andere beperking van het huidige onderzoek is de subjectieve uitkomstmaat waarbij alleen de mening van de diëtist is onderzocht en niet de mening van de cliënt. De totstandkoming van de mening van de diëtist is hierbij niet onderzocht. Wel is de beoordeling door de diëtist ten aanzien van de toereikendheid van vier uur per kalenderjaar in deze studie gecontroleerd met het daadwerkelijk gedeclareerde zorggebruik van de cliënt. Om de nauwkeurigheid van de resultaten in deze studie te vergroten zijn de cliënten bij wie onlogische beoordelingen zijn gegeven uit de analyses gelaten (zie box 1). De onderzochte uitkomstmaat heeft als voordeel dat niet alleen wordt uitgegaan van daadwerkelijk zorggebruik maar juist ook van de inschatting van de diëtist. Misschien worden consulten opzettelijk over het jaar verspreidt, zodat de cliënt gedurende het hele jaar regelmatig een consult heeft en de kosten binnen de vergoeding vanuit de basisverzekering vallen. Door middel van de gebruikte methode heeft de diëtist voor iedere cliënt kunnen aangeven of vier uur diëtetiek per kalenderjaar daadwerkelijk voldoende was of dat het voor de behandeling van de cliënt beter was geweest als hij meer dan vier uur diëtetiek te besteden had gehad. Uit ander onderzoek zal moeten blijken in hoeverre de cliënt tevreden is met vier uur diëtetiek per kalenderjaar. Een sterk punt van deze studie betreft de continue verzameling van specifieke cliëntgegevens gedurende de 
Tol, J., Swinkels, I.C.S., Veenhof, C. Welke cliënten hebben volgens de diëtist voldoende aan vier uur diëtetiek per kalenderjaar? TSG: Tijdschrift voor Gezondheidswetenschappen: 2012, 90(3), 176-183

totale behandeling om het zorgproces inzichtelijk te maken. De onafhankelijke variabelen die in deze studie zijn gebruikt, zijn verzameld door middel van reguliere praktijkadministratie in Evry. Hierdoor is de kans op sociaal wenselijke antwoorden klein.

Uit dit onderzoek blijkt dat volgens de diëtist één op de vijf cliënten onvoldoende heeft aan een vergoeding van vier uur diëtetiek per kalenderjaar. Deze groep bestaat voornamelijk uit vrouwen, cliënten met psychische problemen, verstandelijke problemen, een te hoog lichaamsgewicht, binge-eating disorder, meervoudige diagnosen, of de combinatie van een te hoog lichaamsgewicht en binge-eating disorder of hypertensie. Daarentegen hadden ouderen, cliënten met het eerste consult tussen juli en december en cliënten met een follow-up behandeling vaker voldoende aan vier behandeluren. Daarnaast blijkt dat er tussen vrijgevestigde diëtisten grote verschillen bestaan ten aanzien van het beoordelen of vier uur diëtetiek per kalenderjaar voor een cliënt voldoende is. Meer onderzoek is nodig om te achterhalen waar deze verschillen door komen. Ook is bij cliënten met een tekort aan vier behandeluren per kalenderjaar meer onderzoek nodig naar het resultaat van de behandeling en de benodigde extra behandeltijd.

\section{NooT}

Het LiPZ-project wordt uitgevoerd door het NIVEL in nauwe samenwerking met de Nederlandse Vereniging van Diëtisten, het Koninklijk Nederlands Genootschap voor Fysiotherapie, de Vereniging van Oefentherapeuten Cesar en Mensendieck, Zorgverzekeraars Nederland en het College voor Zorgverzekeringen. LiPZ wordt gefinancierd door het Ministerie van Volksgezondheid, Welzijn en Sport.

\section{LITERATUUR}

1. Ministerie van Volksgezondheid, Welzijn en Sport. Voorhangprocedure AWBZ. Kamerstuk, 16 november 2004. Den Haag: Ministerie van VWS, 2004.

2. Tol J, Swinkels ICS, Leemrijse CJ, Veenhof C. Jaarcijfers 2009 diëtetiek, gegevensverzameling binnen vrijgevestigde praktijken voor diëtetiek. Utrecht: NIVEL, 2010.

3. Leemrijse CJ, Swinkels ICS, Veenhof C, Bakker D de. Jaarboek LiPZ 2006 \& 2007, beroepsgroep diëtetiek, gegevensverzameling binnen vrijgevestigde praktijken voor diëtetiek. Utrecht: NIVEL, 2008.

4. Andersen RM. Revisiting the behavior model and access to medical care: Does it matter? J Health Soc Behav 1995;36:1-10.

5. Nederlandse Vereniging van Diëtisten. Artsenwijzer Diëtetiek. Werkwijze diëtist. Nederlandse Vereniging van Diëtisten, 2010.

6. Jong JD de. Explaining medical practice variation: Social organization and institutional mechanisms (dissertation). Utrecht: NIVEL, 2008.

7. Leemrijse CJ, Bakker D de. Dieetadvies uit de AWBZ: aanloopproblemen de moeite waard? Ned Tijdschr Diëtisten 2004;61(4):107-12.

8. Ministerie van Volksgezondheid, Welzijn en Sport. Beantwoording vragen AO Zorgverzekeringswet/Pakketadvies 2011. Kenmerk CZ/EKZ/3070985, 12 juni 2011. Den Haag: Ministerie van VWS, 2011.

9. Robson T, Blackwell D, Waine C, Kennedy RL. Factors affecting the use of dietetic services by patients with diabetes mellitus. Diabet Med 2001;18:295-300.

10. Britt HC, Valenti L, Miller GC. Determinants of consultation length in Australian general practice. Med J Aust 2005;183:68-71.

11. Lintert $\mathrm{H}$ van, Droomers M, Westert GP. Zorggebruik. In: Tweede nationale studie naar ziekten en verrichtingen in de huisartsenpraktijk. Een kwestie van verschil: verschillen in zelfgerapporteerde leefstijl, gezondheid en zorggebruik. Utrecht: NIVEL, 2004.

12. Centraal Bureau voor de Statistiek. Bevolking, generatie, geslacht, leeftijd en herkomstgroepering, 1 januari. Den Haag/Heerlen: CBS, 2011.

13. Campbell K, Crawford D. Management of obesity: attitudes and practices of Australian dietitians. Int J Obes Relat Metab Disord 2000;24:701-10.

14. Lok KYW, Chan RSM, Sea MMM, Woo J. Nutritionist's variation in counseling style and the effect on weight change of patients attending a community based lifestyle modification program. Int J Environ Res Public Health 2010;7:413-26.

15. Berg MJ van den. Workload in general practice (dissertation). Utrecht: NIVEL, 2010.

16. Jong JD de, Groenewegen PP, Spreeuwenberg P, Schellevis F, Westert GP. Do guidelines create uniformity in medical practice? Soc Sci Med 2010;70:209-216. 


\title{
BOX EN TABELLEN
}

\section{Kernpunten}

- Volgens vrijgevestigde diëtisten heeft één op de vijf cliënten onvoldoende aan vier uur diëtetiek per kalenderjaar.

- Diëtisten oordelen heel verschillend over de vraag of vier uur diëtetiek per kalenderjaar voor een cliënt toereikend is.

- Vier behandeluren wordt vooral te weinig geacht bij vrouwen, cliënten met psychische of verstandelijke problemen, een te hoog lichaamsgewicht, binge-eating disorder of meervoudige diagnosen.

- Vier behandeluren blijkt vaker voldoende bij ouderen, cliënten met het eerste consult tussen juli en december en cliënten met een follow-up behandeling.

\author{
Box 1. Sensitiviteitsanalyse
}

De uitkomstvariabele was oorspronkelijk 6370 maal ingevuld. Echter 758 maal was sprake van administratief falen, waarbij de antwoorden niet correspondeerden met het gedeclareerde zorggebruik van de cliënt. Dit is bijvoorbeeld het geval als een cliënt 120 minuten zorg heeft ontvangen en de diëtist heeft ingevuld dat 240 minuten diëtetiek onvoldoende is. Om de nauwkeurigheid van de resultaten in deze studie te vergroten zijn deze cliënten uit de analyses gelaten. Daarbij is het criterium gehandhaafd dat vier uur diëtetiek als onvoldoende kan zijn beoordeeld als de cliënt minimaal 210 minuten daadwerkelijk zorggebruik heeft ontvangen. De analyses zijn twee keer uitgevoerd; eenmaal met de oorspronkelijke uitkomstvariabele en eenmaal met de gecorrigeerde uitkomstvariabele. De resultaten zijn vergelijkbaar.

Verder zijn de onafhankelijke variabelen bij gemiddeld drie procent van de cliënten in deze studie niet bekend. Om de cliënten met ontbrekende gegevens in de statistische analyse mee te nemen is er voor ontbrekende waarden een categorie "onbekend" aan het statistisch model toegevoegd. Door middel van sensitiviteitsanalyses is er onderzocht in hoeverre het ontbreken van gegevens de resultaten van dit onderzoek hebben beïnvloed. Hierbij zijn verschillende analyses uitgevoerd, waarbij: 1) alleen gegevens van cliënten zonder ontbrekende waarden zijn toegevoegd; 2) alle gegevens zijn toegevoegd met een extra categorie "onbekend" voor ontbrekende waarden; 3) alle gegevens zijn toegevoegd en wanneer meer dan $10 \%$ van de gegevens niet bekend zijn is een extra categorie "onbekend" toegevoegd. Wanneer minder dan 10 procent van de gegevens niet bekend zijn is hieraan de meest voorkomende waarde toegekend. De resultaten tussen deze sensitiviteitsanalyses zijn vergelijkbaar. 
Figuur 1 Verschillen tussen diëtisten onderling in beoordelingswijze ten aanzien van de vraag of vier uur diëtetiek per kalenderjaar toereikend is, gecorrigeerd voor demografische kenmerken, gezondheidsgerelateerde kenmerken en behandelingsgerelateerde kenmerken.

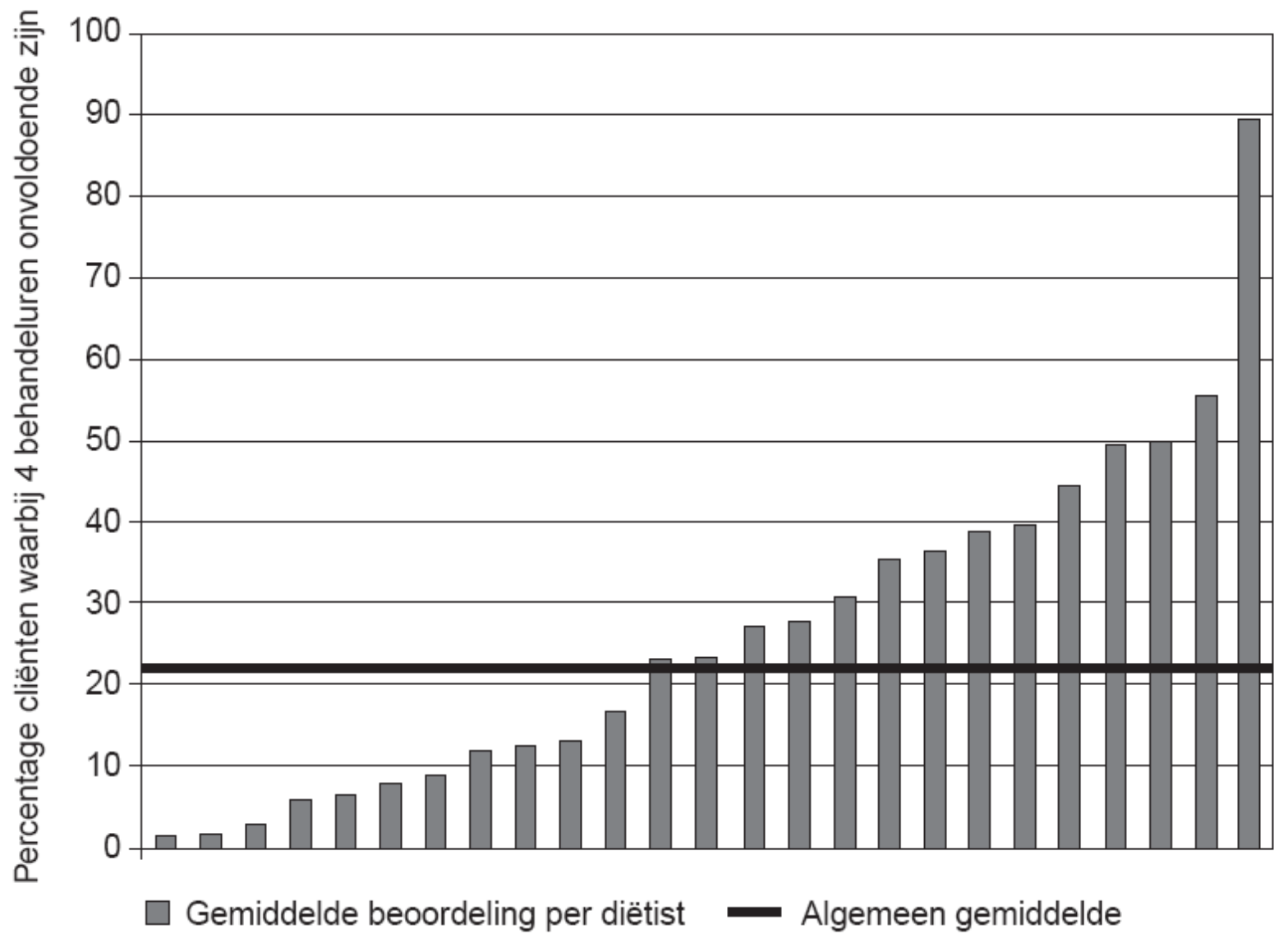

